\title{
Grain yield, and dry matter and nitrogen accumulation and remobilization in durum wheat as affected by variety and seeding rate
}

\author{
I. Arduini ${ }^{\mathrm{a}, *}$, A. Masoni ${ }^{\mathrm{a}}$, L. Ercoli $^{\mathrm{b}}$, M. Mariotti ${ }^{\mathrm{a}}$ \\ a Dipartimento di Agronomia e Gestione dell'Agroecosistema, via S. Michele degli Scalzi 2, 56124 Pisa, Italy \\ ${ }^{\mathrm{b}}$ Scuola Superiore Sant'Anna di Studi Universitari e di Perfezionamento, Piazza Martiri della Libertà 33, 56127 Pisa, Italy
}

Received 8 February 2006; received in revised form 13 June 2006; accepted 19 June 2006

\begin{abstract}
The influence of crop density on the remobilization of dry matter and nitrogen from vegetative plant parts to the developing grain, was investigated in the durum wheat (Triticum durum Desf.) varieties Creso, Simeto and Svevo cultivated in the field at three seeding rates, 200,250 and 400 seeds $\mathrm{m}^{-2}$. Variety $\times$ seeding rate interaction was unsignificant for all recorded characters. Grain yield declined in the order Svevo $>$ Simeto $>$ Creso. Yield differences mainly depended on the different number of kernels per unit land and, secondly, on mean kernel weight. Spike components differed among varieties: Svevo and Simeto showed more kernels per spikelet and Creso more spikelets per spike. Grain yield was highest with 400 seeds $^{-2}$ primarily due to the higher number of spikes per unit area, and secondly, to the higher mean kernel weight. Post-heading dry matter accumulation was highest in Svevo and lowest in Creso, but varieties showed a reverse order for dry matter remobilization and contribution of dry matter remobilization to grain yield. The increase of seeding rate increased both the post-heading dry matter accumulation and the dry matter remobilization from vegetative plant parts to grain. Nitrogen uptake of the whole crop and N content of grain was higher in Simeto and Svevo than in Creso. The N concentration of grain did not vary among varieties, but Svevo showed a markedly lower $\mathrm{N}$ concentration and $\mathrm{N}$ content of culms at maturity, which may be consequence of the high $\mathrm{N}$ remobilization efficiency performed by this variety. The $\mathrm{N}$ uptake by the crop was highest with 400 seeds $\mathrm{m}^{-2}$, but the $\mathrm{N}$ concentration of culms, leaves and even grain was slightly lower than with the lower seed rates. The post-heading $\mathrm{N}$ accumulation was by far higher in Simeto and Svevo than in Creso, whereas remobilization was highest in Svevo and lowest in Simeto. The percentage contribution of $\mathrm{N}$ remobilization to grain $\mathrm{N}$ was by far higher in Creso than in the other two varieties. Post-heading $\mathrm{N}$ accumulation and $\mathrm{N}$ remobilization were highest with the highest plant density, but the contribution of $\mathrm{N}$ remobilization to $\mathrm{N}$ grain content did not differ between seeding rates.
\end{abstract}

(C) 2006 Elsevier B.V. All rights reserved.

Keywords: Triticum durum; Genotype; Row spacing; Yield; N-uptake; N-translocation

\section{Introduction}

In durum wheat as in most other grain crops, maximum grain yield results from an optimum balance of three yield components: (i) the number of spikes per unit land, (ii) the number of kernels per spike and (iii) the weight of single kernels (Grafius, 1972; Prystupa et al., 2004). According to Freeze and Bacon (1990), these yield components have interdependent action and are able to compensate for one another in order to stabilize yield as cultural or climatic conditions change.

Seeding rate and row spacing strongly influence the use of environmental resources by wheat in that they change the relative importance of intraplant and interplant competition for light,

\footnotetext{
* Corresponding author. Tel.: +39050 599208; fax: +39050 560633.

E-mail address: iard@agr.unipi.it (I. Arduini).
}

water and nutrients during crop development (Darwinkel, 1978; Tompkins et al., 1991a,b). Low seed rates decrease interplant competition especially during vegetative growth, but increase intraplant competition during grain filling because plants tend to produce more spike-bearing tillers (Darwinkel, 1978; Marshall and Ohm, 1987). Thus, generally, low seed rates increase the number of spikes produced by each plant and the weight of single spikes, but decrease the number of spikes per unit land, whereas the opposite occurs with high seed rates (Wilson and Swanson, 1962; Tompkins et al., 1991a,b). Whaley et al. (2000) found that the number of kernels per spike increased by $50 \%$ in wheat plants when crop density decreased from 338 to 19 plants $\mathrm{m}^{-2}$, but less than $10 \%$ increases were reported by Ozturk et al. (2006) when seed rate was decreased from 625 to 325 seeds $\mathrm{m}^{-2}$. Compared to the other yield components, kernel weight seems to be less affected by seed rate and was found to be either decreased, or increased or unaffected in response to increasing seed rate 
(Donaldson et al., 2001; Wood et al., 2003; Hiltbrunner et al., 2005). However, Tompkins et al. (1991a,b) reported that the increase of seed rate from 65 to 400 seeds $\mathrm{m}^{-2}$ increased grain yield because the higher number of kernels per spike, obtained with the lower seed rates, was not able to compensate the low number of spikes per unit land. Conversely, Carr et al. (2003) and Wood et al. (2003) found that grain yield of wheat was higher with 250 than with 450 seeds $\mathrm{m}^{-2}$.

Climatic conditions and, especially, rainfall distribution during the growing season were found to modify the response of plants to different spacings. For instance, high seed rates were found to increase yield in well watered conditions, whereas the reverse was true with low soil moisture (Wilson and Swanson, 1962; Blue et al., 1990; Tompkins et al., 1991a,b).

Finally, no marked differences among varieties are reported in the response of grain yield to changing plant density (Spink et al., 2000; Holen et al., 2001; Geleta et al., 2002; Carr et al., 2003). However, Black and Aase (1982) reported that URSS winter wheat cultivars have a greater ability to maintain high kernels per spike at high plant density compared to USA cultivars and, according to Marshall and Ohm (1987) and Anderson and Barclay (1991), the optimal plant population changes according to variety and local conditions. Actually, in central Europe and in Italy narrow row spacings, comprised between 12 and $18 \mathrm{~cm}$, and seed densities of about 400 seeds $\mathrm{m}^{-2}$ are traditionally applied to wheat (Ercoli and Masoni, 1995; Blankenau and Olfs, 2001; Ghaffari et al., 2001), whereas densities around 250 seeds $\mathrm{m}^{-2}$ and even lower are considered optimal for Canada and the United States (Read and Warder, 1982; Donaldson et al., 2001; Carr et al., 2003).

The protein content of grain is of high value for defining the end-use quality of both Triticum aestivum and T. durum grain (Gooding et al., 2003). In T. aestivum, Geleta et al. (2002) reported that grain protein concentration declined as seeding rate increased, probably because of a higher competition among plants for nitrogen. On the other hand, Tompkins et al. (1991a,b) found that grain protein concentration was slightly higher with 470 than with 115 seeds $\mathrm{m}^{-2}$, which they considered a consequence of the higher water use efficiency they recorded in the narrow spaced plants. Finally, Carr et al. (2003) and Ozturk et al. (2006) found that seeding rate did not affect grain protein concentration. The $\mathrm{N}$-use efficiency differed markedly in 16 Italian cultivars of T. aestivum, and the modern high yielding varieties showed both an improved nitrogen uptake and use (Guarda et al., 2004).

In all grain crops the supply of assimilates to the developing grain originates both from current assimilation transferred directly to kernels and from the remobilization of assimilates stored temporarily in vegetative plant parts (Gebbing et al., 1999). The reserves deposited in vegetative plant parts before anthesis may buffer grain yield when conditions become adverse to photosynthesis and mineral uptake during grain filling (Austin et al., 1977; Tahir and Nakata, 2005). The relative importance of current assimilation and remobilization changes among genotypes and is strongly related to environmental conditions. In 25 durum wheat varieties grown in Central Italy, Mariotti et al. (2003) found that the contribution of pre-anthesis assimi- lates to kernel weight ranged from 43 to $54 \%$, and Przulj and Momcilovic (2001a) found that this contribution varied from 4 to $24 \%$ in 20 two-rowed spring barley cultivars. The latter authors also found differences among cultivars in the pre-anthesis accumulation of both dry matter and nitrogen that were related to differences in $\mathrm{N}$ translocation (Przulj and Momcilovic, 2001b). Van Herwaarden et al. (1998) found that the apparent contribution of stored assimilates to grain yield was 37-39\% under high rainfall conditions during grain filling, but arised to $75-100 \%$ under dry field conditions. Tahir and Nakata (2005), however, reported that post-anthesis heat stress increased the remobilization efficiency of non-structural carbohydrates but decreased that of nitrogen.

The effect of plant spacing on the remobilization of assimilates from vegetative plant parts to wheat grain has not been investigated previously. In durum wheat, the influence of plant density on remobilization patterns is of high concern because this crop is mainly grown in areas where climatic conditions are mostly favorable to pre-anthesis growth but drought conditions may severely limit $\mathrm{C}$ assimilation and mineral uptake during grain filling. In bread wheat, Tompkins et al. (1991a,b) reported that pre-anthesis biomass was higher with high seed rates and Przulj and Momcilovic (2001a) found a high positive correlation between biomass at anthesis and both yield and translocation.

The objectives of this study were to examine, under field conditions, the effect of different seeding rates on the grain yield and its components and on the nitrogen uptake of durum wheat (Triticum durum Desf.). The phenological development of the crop and the accumulation of dry matter and nitrogen at heading and at maturity were recorded too, in order to assess the contribution of pre- and post-anthesis assimilates to grain yield. Three varieties were used, in order to compare the response of old and recent Italian genotypes.

\section{Materials and methods}

The research was carried out in the years 2001-2003 at the experimental station of the Department of Agronomy and Agroecosystem Management of the University of Pisa, Italy, that is located at a distance of approximately $10 \mathrm{~km}$ from the sea $\left(43^{\circ} 40^{\prime} \mathrm{N}, 10^{\circ} 19^{\prime} \mathrm{E}\right)$ and $1 \mathrm{~m}$ above sea level. The climate is cold, humid Mediterranean with mean annual maximum and minimum daily air temperatures of 20.2 and $9.5^{\circ} \mathrm{C}$, respectively, and precipitation of $971 \mathrm{~mm}$, with $688 \mathrm{~mm}$ received during the period of durum wheat cultivation, that is from November through July (Moonen et al., 2001).

Soil chemical and physical properties were $34 \%$ sand $(2 \mathrm{~mm}>\varnothing>0.05 \mathrm{~mm}), 21 \%$ silt $(0.05 \mathrm{~mm}>\varnothing>0.002 \mathrm{~mm})$, $45 \%$ clay $(\varnothing<0.002 \mathrm{~mm}), 7.2 \mathrm{pH}, 2.2 \%$ organic matter (Walkley and Black method), $1.2 \mathrm{~g} \mathrm{~kg}^{-1}$ total $\mathrm{N}$ (Kjeldahl method), $33 \mathrm{mg} \mathrm{kg}^{-1}$ available $\mathrm{P}$ (Olsen method), $22 \mathrm{mg} \mathrm{kg}^{-1}$ available K (Dirks-Sheffer method). Field capacity and permanent wilting point determined with the pressure chamber method were 34.1 and $21.2 \%$ at 33 and $1500 \mathrm{kPa}$ soil water tension.

In each year, treatments were the durum wheat $(T$. durum Desf.) varieties Creso, Simeto and Svevo, and the seeding rates: 
200, 250 and 400 seeds $\mathrm{m}^{-2}$. The seeding rates were obtained spacing rows at 28,20 and $12 \mathrm{~cm}$, respectively, and leaving the same distance between plants within each row.

Creso (*IT 40) is an old durum wheat variety (1974) that was widely cultivated in Central Italy in the past 20 years and is still in use. It is characterized by a moderate but constant yield and a high adaptability to different environmental conditions. Simeto (*IT 60) and Svevo (*IT 2) are more recent varieties characterized by taller size and higher productivity.

In both years the preceding crop was berseem (Trifolium alexandrinum L.). Soil was ploughed at $40 \mathrm{~cm}$ depth in November and sowing was performed on 17 November 2001 and on 14 November 2002 by means of a plot drill.

Nitrogen, as urea, phosphorus, as triple superphosphate, and potassium, as $\mathrm{K}_{2} \mathrm{SO}_{4}$ fertilizers were applied before seeding at rates of $30 \mathrm{~kg} \mathrm{ha}^{-1}$ of $\mathrm{N}$ and $150 \mathrm{~kg} \mathrm{ha}^{-1}$ of $\mathrm{P}_{2} \mathrm{O}_{5}$ and $\mathrm{K}_{2} \mathrm{O}$. At the end of tillering, additional $120 \mathrm{~kg} \mathrm{ha}^{-1}$ of $\mathrm{N}$, as urea, were applied. Fertilization was that conventionally applied to wheat in Tuscany (Italy). Weed control was performed at the stage of 4th-5th leaf unfolded by distributing a commercial graminicide. In the second year, three irrigations were performed during grain filling, in order to avoid severe water stress. Each time, a water volume equal to available water was applied by means of sprinkler irrigation.

To determine translocation during grain filling, plants were harvested at heading (stage 59, Zadoks scale, Zadoks et al., 1974 ) and physiological maturity (stage 92 , Zadoks scale). The experiment was arranged in a split-split-plot design with three replications. Year was the whole plot, durum wheat variety the sub-plot and seeding rate the sub-sub-plot.

The phenological stage of the wheat crop was periodically recorded following Zadoks et al. (1974). Heading was reached by the varieties Svevo and Simeto on 22-26 April and by the variety Creso on 2-5 May. Physiological maturity was achieved by all varieties on 20-25 June. At heading and at physiological maturity, plants from four adjacent rows of $1 \mathrm{~m}$ were manually cut at ground level. Plants were separated into culms, spikes and green and dead leaves at heading, and into culms, leaves, chaff and grain at maturity. For dry weight determination, samples from all plant parts were oven dried at $70^{\circ} \mathrm{C}$ to constant weight. At both harvests, the total number of culms and spikes was recorded, and the percentage of head bearing culms was calculated. At heading, the number of spikelets of 50 spikes for each replicate was counted and the area of green leaves was determined by means of a Leica Quantimet 500 image analyzer. At maturity, plant height and mean kernel dry weight were also determined, and the number of kernels per unit area, per spike and per spikelet and Harvest index (HI) were estimated. Plant samples were analyzed for nitrogen (microKjeldahl) concentration and $\mathrm{N}$ content was calculated by multiplying the element concentration by dry weight.

The post-heading dry matter (DM) and $\mathrm{N}$ accumulation were calculated as the difference between DM or N content of the aerial plant part at physiological maturity and at heading.

The dry matter and $\mathrm{N}$ remobilization during grain filling (DMR and NR) were calculated following Cox et al. (1986) and Papakosta and Gagianas (1991), as
$\mathrm{DMR}=\mathrm{DM}$ of the aerial plant part at heading

$-(\mathrm{DM}$ of leaves + culms + chaff at maturity);

$\mathrm{NR}=\mathrm{N}$ content of the aerial plant part at heading

$-(\mathrm{N}$ content of leaves + culms + chaff at maturity $)$.

For these estimates, it was assumed that all of the dry matter and $\mathrm{N}$ lost from vegetative plant parts were translocated to the developing grain, since losses of dry matter due to plant respiration and losses of $\mathrm{N}$ due to volatilization during grain filling were not determined.

The dry matter and $\mathrm{N}$ remobilization efficiency (DMRE and NRE) were calculated as

$\mathrm{DMRE}=(\mathrm{DMR} / \mathrm{DM}$ of the aerial plant part at heading $) \times 100$;

$\mathrm{NRE}=(\mathrm{NR} / \mathrm{N}$ content of the aerial plant part at heading $)$

$$
\times 100 \text {. }
$$

The contribution of pre-heading DM and $\mathrm{N}$ assimilates to grain were calculated as

$\mathrm{CDMRG}=(\mathrm{DMR} / \mathrm{DM}$ of grain at maturity $) \times 100 ;$

$\mathrm{CNRG}=(\mathrm{NR} / \mathrm{N}$ content of grain at maturity $) \times 100$.

Data were statistically treated by ANOVA, in order to test the main effects of year, seed rate and variety and their interactions. Separate statistical analyses were conducted for dry matter and $\mathrm{N}$ accumulation and remobilization for each harvest. Because the main effect of year and its interactions were not significant, a successive analysis of variance was carried out using years as replications. Duncan's multiple range test was used to separate the means when the ANOVA $F$-test indicated a significant effect of the treatment (Steel et al., 1997).

\section{Results}

In the years we carried out the research, temperature during the entire crop cycle and rainfall until anthesis were in line with the 120-year averages (Moonen et al., 2001). In contrast, rainfall during grain filling (May-June) diverged from the average and differed markedly between the 2 years (Fig. 1). In particular, taking into account the last 60 years, only 10 times May and June were wetter than in 2002, and these 2 months were never drier than in 2003. Thus, in order to avoid water stress, in the second year, we irrigated starting from the beginning of May. As a consequence, the crop received an optimal water supply during grain filling in both years, which probably caused the effect of year to be unsignificant in the present research.

The variety $\times$ seeding rate interaction was nonsignificant for all traits measured. Considering that Creso, Simeto and Svevo well represent the durum wheat varieties cultivated in Central Italy, these results provide evidence that the response of durum wheat to seeding rate is not affected by genotype. Therefore, 

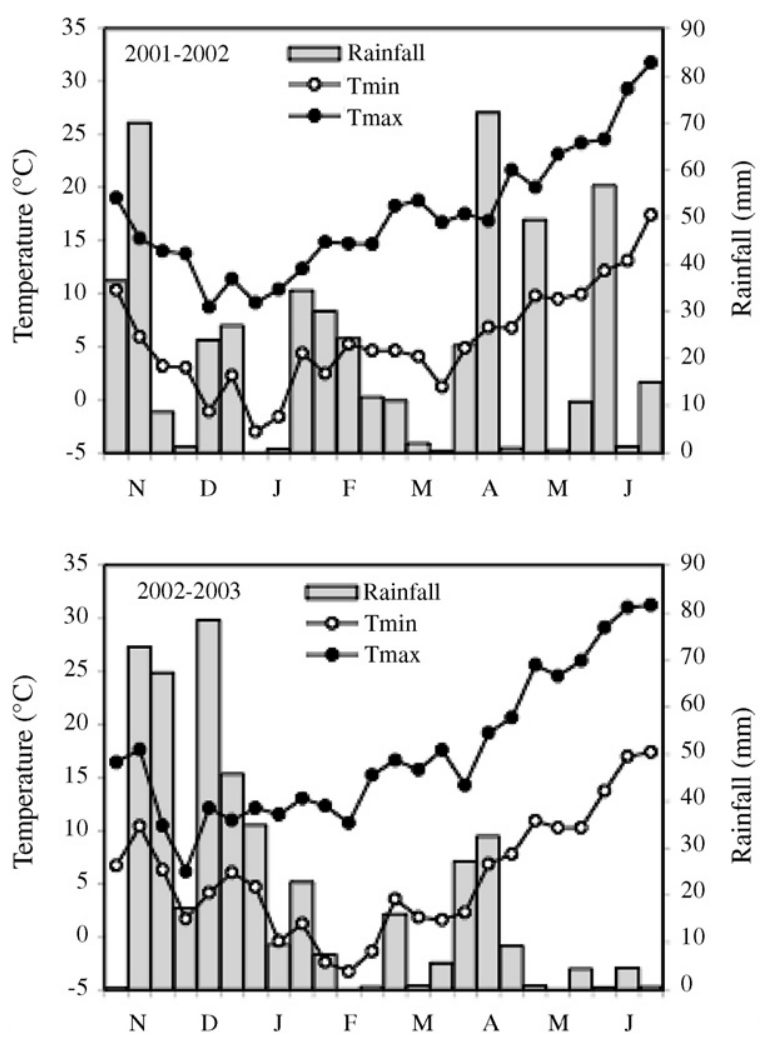

Fig. 1. Minimum and maximum temperatures and rainfall recorded during the period of wheat growth (November-June) in 2001-2002 and 2002-2003.

only variety and seeding rate mean effects were discussed in the present paper.

The duration of the entire cycle did not vary significantly among varieties and seeding rates, averaging 215 days. However, in the variety Creso the stage of first node detectable (31, Zadoks scale) was achieved 6-9 days later than in the varieties Simeto and Svevo, while the grain filling period was 6-8 days shorter.

The highest grain yield was $7.2 \mathrm{tha}^{-1}$, and it was obtained with the variety Svevo sown at 400 seeds $^{-2}$. Averaged over seeding rates, grain yield of Svevo exceeded by $67 \%$ that of Creso and by $37 \%$ that of Simeto (Fig. 2 left). The higher grain yield of Svevo (Table 1) depended mainly on the number of kernels per unit surface, that was by 55 and $31 \%$ higher than in Creso and in Simeto, whereas the mean kernel weight con- tributed to a smaller extent, +7 and $+1 \%$, respectively. Compared to Simeto, the increased number of kernels per unit surface of Svevo was mainly consequence of the higher number of spikes per unit surface $(+21 \%)$, and only secondly of the number of kernels per spike (+9\%), while, compared to Creso, the latter contributed more than the former ( +36 and $+14 \%$, respectively). The higher number of kernels per spike achieved in Svevo was due to the higher number of kernels per spikelet, that was by 63 and 15\% higher than in Creso and Simeto, respectively. The number of spikelets per spike had an inverse trend compared to the other grain yield components (Table 1). Finally, the var. Svevo also showed the highest harvest index, 39 compared to $32 \%$ of Simeto and $28 \%$ of Creso, together with the highest size of plants at maturity, 112 compared to $107 \mathrm{~cm}$ (data not shown).

The green leaf area recorded at heading ranged from $514 \mathrm{dm}^{2} \mathrm{~m}^{-2}$ of the var. Svevo to $564 \mathrm{dm}^{2} \mathrm{~m}^{-2}$ of Simeto and for all varieties it increased linearly with the increase of seeding rate (Table 1).

Averaged over varieties, the grain yield obtained with 400 seeds $\mathrm{m}^{-2}$ was by 42 and $21 \%$ higher than that obtained with 200 and 250 seeds $\mathrm{m}^{-2}$ (Fig. 2 right). The increase in grain yield was essentially due to the increased number of kernels per unit area, and we found a positive relationship between these two parameters (Fig. 3). The number of kernels per unit area depended primarily on the increased number of spikes per unit area (+45 and 24\%), and secondly on the higher mean kernel weight (+12 and 5\%) (Table 1). In contrast, the number of kernels per spike decreased with the increase of seeding rate from 30 to 26, and the number of kernels per spikelet and that of spikelets per spike were not affected by seeding rate. Harvest index slightly increased with the increase of seeding rate from 200 to 400 seeds $\mathrm{m}^{-2}$, and was 32,34 and $35 \%$. In addition, plants grown with the lowest seed rate were by $8 \mathrm{~cm}$ taller than other plants (114 compared to $106 \mathrm{~cm}$ ).

The dry weight of culms and leaves did not differ statistically among varieties at both harvests, and that of spikes only at maturity and essentially in consequence of the differences in grain dry weight (data not shown).

Between heading and maturity, the number of spikes per unit area increased by $5 \%$ in Creso, by $13 \%$ in Simeto and by $22 \%$ in Svevo (Table 1). The dry weight of culms and leaves decreased, while that of spikes increased with patterns that differed among varieties mainly according to differences in grain yield (data not

Table 1

Spike number, mean kernel weight, kernel and spikelet number and green leaf area of Triticum durum as affected by variety and seeding rate

\begin{tabular}{|c|c|c|c|c|c|c|c|c|}
\hline \multirow[t]{2}{*}{ Treatments } & \multicolumn{2}{|c|}{ Spike number $\left(\mathrm{n} \mathrm{m}^{-2}\right)$} & \multirow{2}{*}{$\begin{array}{l}\text { Kernel weight } \\
(\mathrm{mg})\end{array}$} & \multirow{2}{*}{$\begin{array}{l}\text { Kernel per square } \\
\text { meter (no.) }\end{array}$} & \multirow{2}{*}{$\begin{array}{l}\text { Kernel per spike } \\
\text { (no.) }\end{array}$} & \multirow{2}{*}{$\begin{array}{l}\text { Kernel per } \\
\text { spikelet (no.) }\end{array}$} & \multirow{2}{*}{$\begin{array}{l}\text { Spikelet per spike } \\
\text { (no.) }\end{array}$} & \multirow{2}{*}{$\begin{array}{l}\text { Green leaf area } \\
\left(\mathrm{dm}^{2} \mathrm{~m}^{-2}\right)\end{array}$} \\
\hline & Heading & Maturity & & & & & & \\
\hline \multicolumn{9}{|l|}{$\overline{\text { Variety }}$} \\
\hline Simeto & $380 \mathrm{~b}$ & $430 a$ & $40.6 \mathrm{a}$ & $12,069 \mathrm{~b}$ & $28.1 \mathrm{~b}$ & $1.4 \mathrm{~b}$ & $20.2 b$ & $563.9 \mathrm{a}$ \\
\hline Svevo & $426 \mathrm{a}$ & $519 b$ & $41.0 \mathrm{a}$ & $15,854 \mathrm{c}$ & $30.6 \mathrm{c}$ & $1.6 \mathrm{c}$ & $19.1 \mathrm{~b}$ & $513.6 \mathrm{~b}$ \\
\hline \multicolumn{9}{|c|}{ Seeding rate (seeds $\mathrm{m}^{-2}$ ) } \\
\hline 400 & $483 c$ & $563 \mathrm{c}$ & $44.0 \mathrm{~b}$ & $14,545 b$ & $25.8 \mathrm{~b}$ & $1.3 \mathrm{a}$ & $20.2 \mathrm{a}$ & $599.5 \mathrm{~b}$ \\
\hline
\end{tabular}

For each treatment, values in a column followed by the same letter are not significantly different at $P \leq 0.05$ as determined by the Duncan's test. 

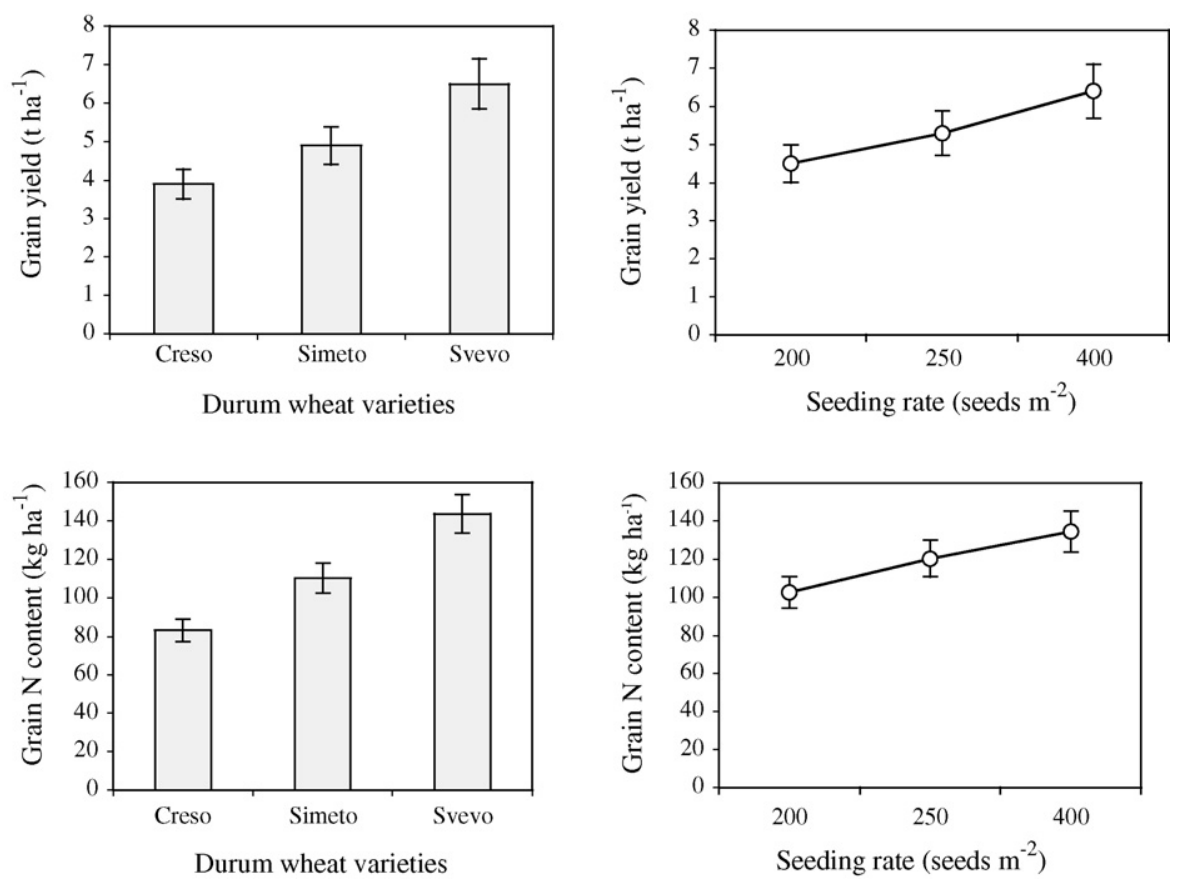

Fig. 2. Grain yield and grain $\mathrm{N}$ content of durum wheat as affected by variety (left) and seeding rate (right). Bars represent \pm S.E.

shown). As a result, the overall post-heading dry matter accumulation of Svevo was by $60 \%$ higher than that of Simeto and by $174 \%$ than that of Creso (Fig. 4 left). The reverse occurred for dry matter remobilization that was by 21 and 53\% higher in Creso than in Simeto and in Svevo, respectively. Thus, in Creso post-heading DM accumulation and remobilization contributed equally to grain yield, while in Simeto accumulation was double than remobilization and in Svevo it was four-fold higher. So, grain yield depended for one half on remobilization in Creso, for a third party in Simeto and only for a fifth party in Svevo. Finally, in all varieties, the cumulative dry matter remobilization from culms was approximately double than that from leaves.

At both harvest stages, the dry weight of all plant parts increased with the increase of seed rate, with differences that were always statistically significant between 200 and 400 seeds $\mathrm{m}^{-2}$ (Table 2). As a result, the dry weight of the aerial part increased by $30 \%$ between the lowest and the high-

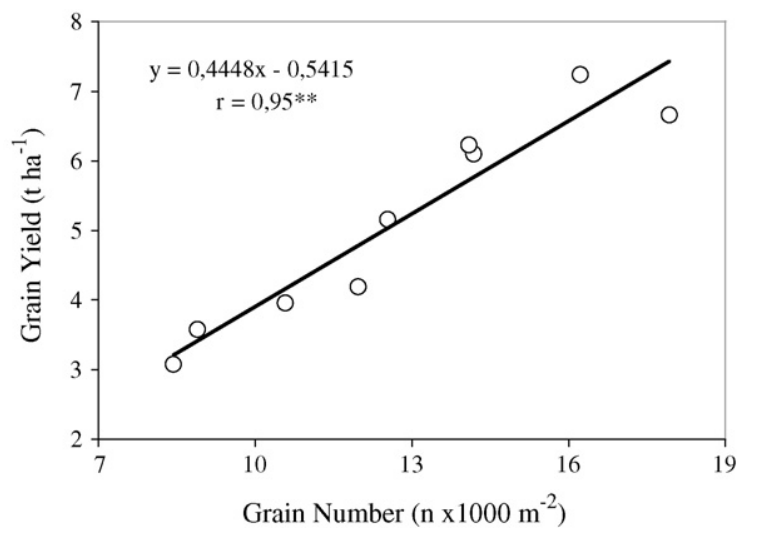

Fig. 3. Relationship between grain yield and grain number per unit area for different varieties and seeding rates. est seed rate at both stages. Between heading and maturity, the dry weight of spikes increased approximately six-fold, without appreciable variations among seeding rates. In the same period, the dry weight of culms and leaves decreased. The reduction of culm dry weight depended on seed rate, and increased from 1.4 to $2.5 \mathrm{tha}^{-1}$ with the increase of seed rate, whereas leaf dry weight was seed rate independent and was approximately 1 tha $^{-1}$.

Both post-heading dry matter accumulation and translocation increased with seeding rate (Fig. 4 right). The former, however, did not differ between the two lower seed rates, and increased by $30 \%$ with the highest one, whereas the latter increased most between 200 and 250 seeds $\mathrm{m}^{-2}(+64 \%)$ and then only by $11 \%$. Post-heading dry matter accumulation was about threefold higher than remobilization at the lowest seeding rate and two-fold higher with the other two rates. Finally, the contribution of remobilization to grain yield ranged from 25 to $34 \%$, with the

Table 2

Dry weight of culms, leaves, spikes and aerial part of Triticum durum at heading and physiological maturity as affected by seeding rate

\begin{tabular}{lllll}
\hline Seeding rate $\left(\right.$ seeds $\left.^{-2}\right)$ & \multicolumn{4}{l}{ Dry weight $\left(\mathrm{t} \mathrm{ha}^{-1}\right)$} \\
\cline { 2 - 5 } & Culms & Leaves & Spikes & Aerial part \\
\hline Heading & & & & \\
200 & $6.8 \mathrm{a}$ & $2.6 \mathrm{a}$ & $1.2 \mathrm{a}$ & $10.6 \mathrm{a}$ \\
250 & $7.8 \mathrm{~b}$ & $2.9 \mathrm{~b}$ & $1.3 \mathrm{ab}$ & $12.0 \mathrm{ab}$ \\
400 & $9.3 \mathrm{c}$ & $3.0 \mathrm{~b}$ & $1.5 \mathrm{ab}$ & $13.8 \mathrm{~b}$ \\
Maturity & & & & \\
200 & $5.4 \mathrm{a}$ & $1.6 \mathrm{a}$ & $7.0 \mathrm{a}$ & $14.0 \mathrm{a}$ \\
250 & $5.8 \mathrm{a}$ & $1.9 \mathrm{ab}$ & $7.8 \mathrm{a}$ & $15.5 \mathrm{a}$ \\
400 & $6.8 \mathrm{~b}$ & $2.2 \mathrm{~b}$ & $9.2 \mathrm{~b}$ & $18.2 \mathrm{~b}$
\end{tabular}

For each harvest, values in a column followed by the same letter are not significantly different at $P \leq 0.05$ as determined by the Duncan's test. 

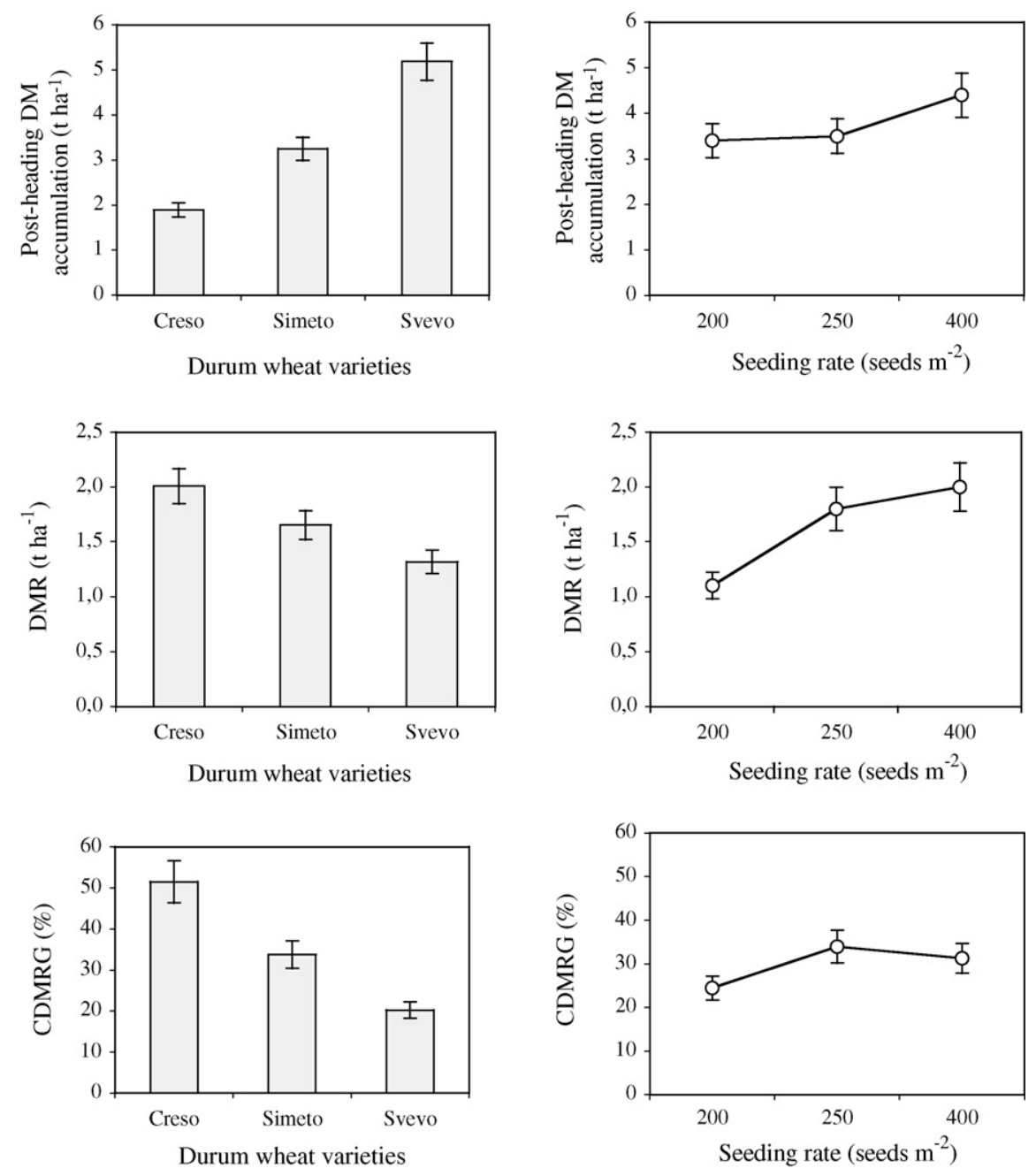

Fig. 4. Post-heading dry matter accumulation, dry matter remobilization (DMR), and contribution of dry matter remobilization to grain yield (CDMRG) of durum wheat as affected by variety (left) and seeding rate (right). Bars represent \pm S.E.

lowest value recorded with 200 seeds $^{-2}$ and the highest with 250 seeds $\mathrm{m}^{-2}$. Culms translocated more dry matter than leaves and the ratio between the dry matter remobilized by culms and by leaves increased from 1.4 to 2.0 and to 3.1 with the increase of seeding rate.

The $\mathrm{N}$ concentration of separate plant parts did not differ significantly among varieties at heading. At maturity, the var. Svevo showed a lower $\mathrm{N}$ concentration of culms ( 2.5 compared to $4.6 \mathrm{~g} \mathrm{~N} \mathrm{~kg}^{-1}$ of Creso and Simeto) and the var. Simeto a higher $\mathrm{N}$ concentration of leaves (13.6 compared to $10.2 \mathrm{~g} \mathrm{~N} \mathrm{~kg}^{-1}$ of Creso and Svevo), whereas the $\mathrm{N}$ concentrations of spikes, grain and of the entire aerial part were not affected by variety (data not shown). The increase of plant density decreased the $\mathrm{N}$ concentration of culms, leaves and grain, but differences were significant only when plant density increased from 250 to 400 seeds $\mathrm{m}^{-2}$ (Table 3).

At heading, the $\mathrm{N}$ content of culms, leaves and spikes did not differ appreciably among varieties. At maturity, the $\mathrm{N}$ content of both culms and leaves was lower in the var. Svevo compared to the other two varieties, by approximately 45 and $25 \%$ (Table 4). Conversely, grain $\mathrm{N}$ content was highest in the cv. Svevo, with values that were 30\% higher than in Simeto and $73 \%$ higher than in Creso (Fig. 2 left). Finally, the $\mathrm{N}$ content of the entire aerial part was approximately $190 \mathrm{~kg} \mathrm{~N} \mathrm{ha}^{-1}$ in Simeto and Svevo and $150 \mathrm{~kg} \mathrm{~N} \mathrm{ha}^{-1}$ in Creso (Table 4).

Between heading and maturity, $\mathrm{N}$ concentration and $\mathrm{N}$ content of culms and leaves decreased in all varieties, whereas those of spikes and of the entire aerial part increased.

Table 3

Nitrogen concentration of culms, leaves, spikes, grain and aerial part of Triticum durum at heading and physiological maturity as affected by seeding rate

\begin{tabular}{llllll}
\hline Seeding rate $\left(\right.$ seeds $\left.^{-2}\right)$ & \multicolumn{5}{l}{ Nitrogen concentration $\left(\mathrm{g} \mathrm{kg}^{-1}\right)$} \\
\cline { 2 - 6 } & Culms & Leaves & Spikes & Grain & Aerial part \\
\hline Heading & & & & & \\
200 & $6.3 \mathrm{a}$ & $18.7 \mathrm{a}$ & $11.3 \mathrm{a}$ & - & $9.9 \mathrm{a}$ \\
250 & $6.1 \mathrm{a}$ & $18.2 \mathrm{a}$ & $11.6 \mathrm{a}$ & - & $9.6 \mathrm{a}$ \\
400 & $5.4 \mathrm{~b}$ & $16.5 \mathrm{~b}$ & $10.8 \mathrm{a}$ & - & $8.4 \mathrm{a}$ \\
Maturity & & & & & \\
200 & $4.4 \mathrm{a}$ & $12.2 \mathrm{a}$ & $17.2 \mathrm{a}$ & $22.8 \mathrm{a}$ & $11.7 \mathrm{a}$ \\
250 & $4.3 \mathrm{a}$ & $12.2 \mathrm{a}$ & $17.4 \mathrm{a}$ & $22.7 \mathrm{a}$ & $11.6 \mathrm{a}$ \\
400 & $3.2 \mathrm{~b}$ & $9.7 \mathrm{~b}$ & $16.4 \mathrm{a}$ & $21.0 \mathrm{~b}$ & $10.7 \mathrm{a}$ \\
\hline
\end{tabular}

For each harvest, values in a column followed by the same letter are not significantly different at $P \leq 0.05$ as determined by the Duncan's test. 
Table 4

Nitrogen content of culms, leaves, spikes and entire aerial part of Triticum durum at heading and physiological maturity as affected by variety

\begin{tabular}{lllll}
\hline Variety & \multicolumn{4}{l}{ Nitrogen content $\left(\mathrm{kg} \mathrm{ha}^{-1}\right)$} \\
\cline { 2 - 5 } & Culms & Leaves & Spikes & Aerial part \\
\hline Heading & & & & \\
Creso & $46.8 \mathrm{a}$ & $54.1 \mathrm{a}$ & $14.2 \mathrm{a}$ & $115.1 \mathrm{a}$ \\
Simeto & $49.4 \mathrm{a}$ & $52.1 \mathrm{a}$ & $15.9 \mathrm{a}$ & $117.3 \mathrm{a}$ \\
Svevo & $44.5 \mathrm{a}$ & $44.5 \mathrm{a}$ & $14.8 \mathrm{a}$ & $103.8 \mathrm{~b}$ \\
Maturity & & & & \\
Creso & $26.7 \mathrm{a}$ & $22.2 \mathrm{a}$ & $100.0 \mathrm{a}$ & $148.9 \mathrm{a}$ \\
Simeto & $28.1 \mathrm{a}$ & $24.5 \mathrm{a}$ & $133.9 \mathrm{~b}$ & $186.4 \mathrm{~b}$ \\
Svevo & $15.0 \mathrm{~b}$ & $17.5 \mathrm{~b}$ & $157.6 \mathrm{c}$ & $190.1 \mathrm{~b}$ \\
\hline
\end{tabular}

For each harvest, values in a column followed by the same letter are not significantly different at $P \leq 0.05$ as determined by the Duncan's test.

The post-heading $\mathrm{N}$ accumulation of the var. Svevo was by $25 \%$ higher than that of Simeto and by $155 \%$ higher than that of Creso, whereas the $\mathrm{N}$ remobilization to grain was higher in Svevo than in Creso (+17\%) and in Simeto (39\%) (Fig. 5 left). A trend similar to $\mathrm{N}$ remobilization was observed for $\mathrm{N}$ remobi-
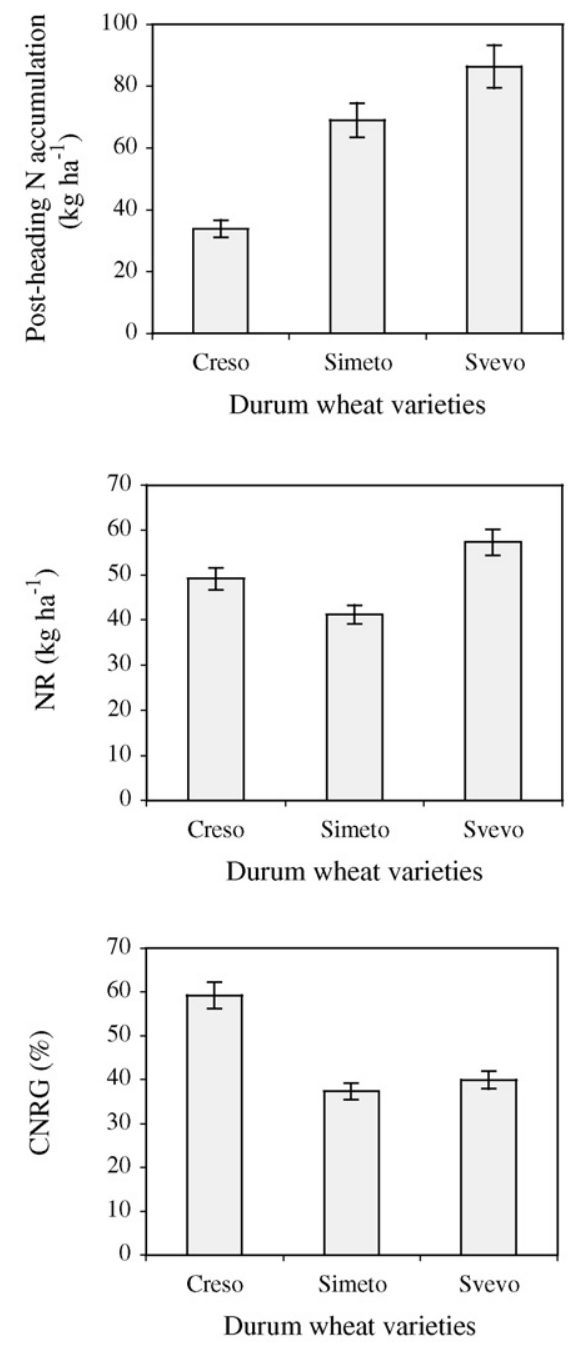

lization efficiency (NRE), that was 55\% in Svevo, $43 \%$ in Creso and $35 \%$ in Simeto (data not shown), whereas the contribution of remobilization to grain $\mathrm{N}$ content was $60 \%$ in Creso and approximately $38 \%$ in the other two varieties (Fig. 5 left). Thus, nitrogen remobilization was by $45 \%$ higher than accumulation in Creso and by $40 \%$ lower in Simeto and Svevo. Remobilization from leaves was higher than from culms in Creso and Simeto, and lower in Svevo.

At heading, $\mathrm{N}$ content of culms and spikes increased by approximately $18 \%$ with the increase of plant density, whereas that of leaves was not affected (Table 5). At maturity, the N content of grain linearly increased with the increase of seeding rate (Fig. 2 right), whereas that of culms and leaves was unchanged among treatments (Table 5). As a result, the $\mathrm{N}$ content of the aerial part was by about $25 \%$ higher with 400 seeds $\mathrm{m}^{-2}$ compared to the two lower seed rates. With all treatments the $\mathrm{N}$ uptake of the aerial part exceeded the amount of $\mathrm{N}$ applied with fertilizers. The surplus ranged from $14 \mathrm{~kg} \mathrm{Nha}^{-1}$ with

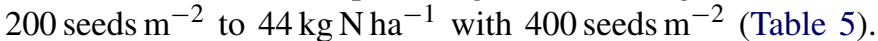
This nitrogen was probably left in soil by the preceding leguminous crop that was T. alexandrinum.
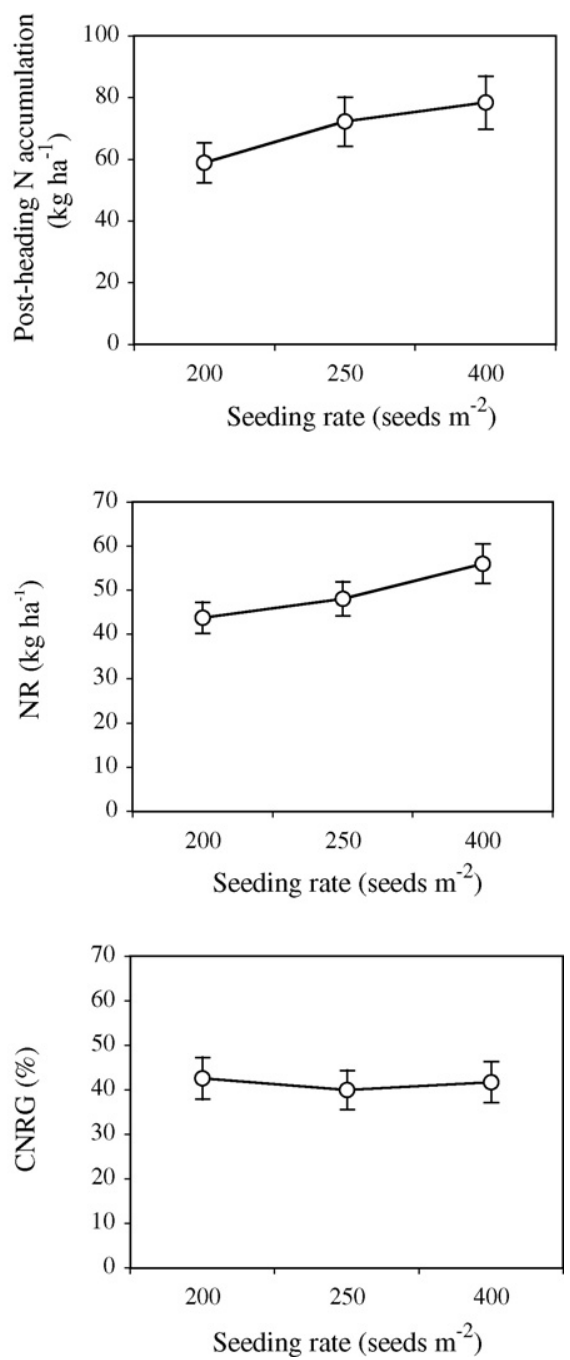

Fig. 5. Post-heading $\mathrm{N}$ accumulation, $\mathrm{N}$ remobilization (NR), and contribution of $\mathrm{N}$ remobilization to $\mathrm{N}$ grain content (CNRG) of durum wheat as affected by variety (left) and seeding rate (right). Bars represent \pm S.E. 
Table 5

Nitrogen content of culms, leaves, spikes and entire aerial part of Triticum durum at heading and physiological maturity as affected by seeding rate

\begin{tabular}{lllll}
\hline Seeding rate $\left(\right.$ seeds $\left.^{-2}\right)$ & \multicolumn{4}{l}{ Nitrogen content $\left(\mathrm{kg} \mathrm{ha}^{-1}\right)$} \\
\cline { 2 - 5 } & Culms & Leaves & Spikes & Aerial part \\
\hline $\begin{array}{lllll}\text { Heading } \\
200\end{array}$ & $42.8 \mathrm{a}$ & $48.6 \mathrm{a}$ & $13.6 \mathrm{a}$ & $105.0 \mathrm{a}$ \\
250 & $47.6 \mathrm{ab}$ & $52.8 \mathrm{a}$ & $15.1 \mathrm{~b}$ & $115.4 \mathrm{~b}$ \\
400 & $50.2 \mathrm{~b}$ & $49.5 \mathrm{a}$ & $16.2 \mathrm{~b}$ & $115.9 \mathrm{~b}$ \\
Maturity & & & & \\
200 & $23.8 \mathrm{a}$ & $19.5 \mathrm{a}$ & $120.6 \mathrm{a}$ & $163.9 \mathrm{a}$ \\
250 & $24.9 \mathrm{a}$ & $23.2 \mathrm{a}$ & $139.6 \mathrm{~b}$ & $187.7 \mathrm{~b}$ \\
400 & $21.8 \mathrm{a}$ & $21.3 \mathrm{a}$ & $151.2 \mathrm{c}$ & $194.3 \mathrm{c}$ \\
\hline
\end{tabular}

For each harvest, values in a column followed by the same letter are not significantly different at $P \leq 0.05$ as determined by the Duncan's test.

Post-heading $\mathrm{N}$ accumulation and $\mathrm{N}$ remobilization increased almost linearly with the increase of seeding rate (Fig. 5 right), but $\mathrm{N}$ accumulation was between 34 and 50\% higher than remobilization. Nitrogen remobilization efficiency was $42 \%$ with 200 and 250 seeds $\mathrm{m}^{-2}$ and fell to $35 \%$ with 400 seeds $\mathrm{m}^{-2}$ (data not shown), whereas the contribution of remobilization to grain $\mathrm{N}$ yield was unchanged by seeding rate and was approximately $40 \%$ (Fig. 5 right). Nitrogen remobilization from leaves was unchanged by seeding rate, while that from culms increased linearly with the increase of seeding rate. As a consequence, with the two lowest seed rates, remobilization from leaves was higher than from culms, while values equalled with the highest seed rate. It is noteworthy that during grain filling the aerial part accumulated more than $35 \%$ of the total $\mathrm{N}$ taken up during the entire cycle.

\section{Discussion}

The durum wheat varieties Creso, Simeto and Svevo did not differ in the patterns of response to plant density. Similar results were reported by several authors for a wide range of T. aestivum genotypes chosen among old and modern, short and tall ones (Spink et al., 2000; Donaldson et al., 2001; Geleta et al., 2002; Carr et al., 2003). Averaged over seed rates, however, the three varieties showed marked differences for most of the recorded characters.

The duration of the entire cycle was similar for the three varieties, but the older var. Creso had a longer vegetative phase and a shorter grain filling period compared to the two modern ones. Earlier heading was also reported by Guarda et al. (2004) as a characteristic of modern Italian varieties of T. aestivum.

Varieties differed in both grain yield and yield components. Grain yield declined in the order Svevo $>$ Simeto $>$ Creso. The higher yield of the newer varieties Svevo and Simeto was essentially due to an increase in the number of fertile florets within each spikelet and in the weight of single kernels. This differences are consistent with those reported between ancient and modern wheat varieties by Siddique et al. (1989), Frederick and Bauer (1999) and Guarda et al. (2004), and are considered the result of an improved partitioning of assimilates to the head.
In the present research, the highest grain yield of durum wheat was obtained with the highest seeding rate. Accordingly, Ghaffari et al. (2001) found that seed rates comprised between 300 and 450 seeds $\mathrm{m}^{-2}$ are optimal for temperate conditions. The analysis of yield components showed that the higher grain yield was primarily due to the higher number of kernels per unit area, directly related to the number of spikes per unit area, and secondly, to the higher mean kernel weight. It is noteworthy that the number of kernels per spike progressively increased with the decrease of seeding rate but, differently from the findings of Darwinkel (1978) and Spink et al. (2000), this yield gain was not enough to fully compensate for the lower number of spikes per unit area. A positive correlation between seed rate and both grain yield and mean kernel weight was reported for T. aestivum by Wilson and Swanson (1962), Blue et al. (1990) and Geleta et al. (2002). Carr et al. (2003) found that the increase of seed density increased yield, but did not affect kernel weight. Opposite results were reported by Wood et al. (2003), who found that grain yield was higher with 250 than with 350 seeds $\mathrm{m}^{-2}$, due to the higher number of grains per ear and the higher mean kernel weight.

The var. Svevo showed a by far higher post-heading dry matter accumulation compared to the var. Simeto and Creso, to which, however, corresponded a consistently lower remobilization. The var. Simeto showed intermediate values for these traits. As a result, the contribution of dry matter remobilization to grain yield differed markedly among the three varieties, being more than $50 \%$ in Creso and less than $20 \%$ in Svevo, which is consistent with the differences between older and newer varieties reported by Pheloung and Siddique (1991). Marked differences among varieties in the relative contribution of pre- and postanthesis assimilates to grain yield were also reported by Przulj and Momcilovic (2001a) for two-rowed barley. These authors also observed that cultivars with a larger contribution of dry matter translocation to grain yield tended to have lower yields. The contribution of pre-anthesis assimilates to grain may be crucial for maintaining yield when adverse climatic conditions reduce photosynthesis and water and mineral uptake (Van Herwaarden et al., 1998; Tahir and Nakata, 2005). Thus, the high contribution of translocates to grain yield observed in Creso may be responsible of its known yield stability over years. Conversely, the low contribution of translocates could impair the var. Svevo to maintain high yield when high temperatures or water stress occur around anthesis, as it was suggested by Frederick and Bauer (1999) for modern high yielding wheat varieties.

The post-heading dry matter accumulation and the dry matter remobilization from vegetative plant parts to grain increased with the increase of seeding rate. A possible explanation of increased accumulation is that the higher number of plants increased both the photosynthetizing area at heading $(+35 \%$ between the lowest and the highest seed rate) and the volume of roots per unit soil surface, allowing the crop to improve the exploitation of environmental resources. Wall and Kanemasu (1990) reported that the early canopy closure obtained with high crop densities increased light interception efficiency and net productivity. In addition, the higher remobilization we found was probably linked to the higher dry matter of the crop at heading, 
that represents the potential source for remobilization (Tompkins et al., 1991a,b; Przulj and Momcilovic, 2001a).

Due to the higher dry matter yield, $\mathrm{N}$ uptake of the whole crop and N content of grain was higher in Simeto and Svevo than in Creso. The $\mathrm{N}$ concentration of grain did not vary among varieties, whereas the var. Svevo showed a markedly lower $\mathrm{N}$ content of culms and leaves at maturity, which may be consequence of the high $\mathrm{N}$ remobilization efficiency performed by this variety. The difference in $\mathrm{N}$ uptake and use we observed between Creso and Svevo is in agreement with results reported by Guarda et al. (2004) for Italian bread-wheat cultivars.

The $\mathrm{N}$ uptake by the crop was highest with 400 seeds $^{-2}$, but only in consequence of increased dry matter, because the $\mathrm{N}$ concentration of culms, leaves and even grain was slightly lower than with other treatments. Contrasting results are reported for the $\mathrm{N}$-uptake of wheat crops in response to plant density. According to Geleta et al. (2002), grain protein concentration declined as seeding rate and yield increased, suggesting that more fertilizer could be required to maintain a better end-use quality of wheat at higher seed rates. In contrast, Tompkins et al. (1991a,b) found that high seed rates increased grain protein concentration and, finally, Carr et al. (2003) and Ozturk et al. (2006) found that grain protein concentration did not change also with wider ranges of seeding rate. Justes et al. (1994) proposed a valuable relationship between crop mass and crop $\mathrm{N}$ content to verify if the crop is or not in situation of non-limiting concentration. The application of this relationship to our data indicated that nitrogen was never limiting for crop growth.

Consistently to what observed for dry matter, also the postheading $\mathrm{N}$ accumulation was by far higher in Simeto and Svevo than in Creso, whereas remobilization showed different patterns and was highest in Svevo and lowest in Simeto. Nevertheless, the percentage contribution of $\mathrm{N}$ remobilization to grain $\mathrm{N}$ was by far higher in Creso than in the other two varieties. In contrast, Przulj and Momcilovic (2001b) found that higher post-anthesis $\mathrm{N}$ accumulation was related to lower $\mathrm{N}$ remobilization in spring barley varieties. Our results suggest that the var. Svevo is very efficient in $\mathrm{N}$ use, similarly to bread-wheat varieties recently selected in Italy (Guarda et al., 2004).

The post-heading $\mathrm{N}$ accumulation of the durum wheat crop and the $\mathrm{N}$ remobilization were highest with the highest plant density, but the contribution of remobilization to $\mathrm{N}$ grain content did not differ between the lowest and the highest seeding rate.

In conclusion, the highest grain yield was obtained with 400 seeds $\mathrm{m}^{-2}$, which caused a slight decrease in the $\mathrm{N}$ concentration of grain but did not affect the general $\mathrm{N}$ nutrition status of the crop estimated according to Justes et al. (1994). The grain yield increase was essentially due to the higher number of spikes per unit surface and to the higher biomass of the crop at heading that allowed a higher remobilization of resources to the developing grain. The three varieties differed essentially in harvest index and in the post-heading accumulation and translocation of both dry matter and nitrogen. The highest grain yield was obtained with the variety Svevo, that showed the highest post-heading accumulation of both dry matter and nitrogen, the best $\mathrm{N}$ remobilization efficiency but the lowest dry matter translocation. We must mention that present results were obtained with optimal growth conditions, especially with respect to water supply during the grain filling period. These conditions could have delayed senescence allowing plants to photosynthetize and assimilate for a longer period.

\section{References}

Anderson, W.K., Barclay, J., 1991. Evidence for differences between three wheat cultivars in yield response to plant population. Aust. J. Agric. Res. 42, 701-713.

Austin, R.B., Edrich, J.A., Ford, M.A., Blackwell, R.D., 1977. The fate of dry matter, carbohydrates and ${ }^{14} \mathrm{C}$ lost from the leaves and stems of wheat during grain filling. Ann. Bot. 41, 1309-1321.

Black, A.L., Aase, J.K., 1982. Yield component comparisons between USA and USSR winter wheat cultivars. Agron. J. 74, 436-441.

Blankenau, K., Olfs, H.-W., 2001. Effect of different crop densities of winter wheat on recovery of nitrogen in crop and soil within the growth period. J. Agron. Crop Sci. 186, 151-156.

Blue, E.N., Mason, S.C., Sander, D.H., 1990. Influence of planting date, seeding rate, and phosphorus rate on wheat yield. Agron. J. 82, 762768

Carr, P.M., Horsley, R.D., Poland, W.W., 2003. Tillage and seeding rate effects on wheat cultivars. I. Grain production. Crop Sci. 43, 202-209.

Cox, M.C., Qualset, C.O., Rains, D.W., 1986. Genetic variation for nitrogen assimilation and translocation in wheat. III. Nitrogen translocation in relation to grain yield and protein. Crop Sci. 26, 737-740.

Darwinkel, A., 1978. Patterns of tillering and grain production of winter wheat at a wide range of plant densities. Neth. J. Agric. Sci. 26, 383-398.

Donaldson, E., Schillinger, F.W., Dofing, S.M., 2001. Straw production and grain yield relationships in winter wheat. Crop Sci. 41, 100-106.

Ercoli, L., Masoni, A., 1995. Effects of row spacing and orientation on yield and yield components of winter wheat. Agric. Med. 125, 215-221.

Frederick, J.R., Bauer, P.J., 1999. Physiological and numerical components of wheat yield. In: Satorre, E.H., Slafer, G.A. (Eds.), Wheat: Ecology and Physiology of Yield Determination. Haworth Press, Inc., New York, USA, pp. 45-65.

Freeze, D.M., Bacon, R.K., 1990. Row-spacing and seeding rate effects on wheat yields in the Mid-South. J. Prod. Agric. 3, 345-348.

Gebbing, T., Schnyder, H., Kühbauch, W., 1999. The utilization of pre-anthesis reserves in grain filling of wheat. Assessment by steady-state ${ }^{13} \mathrm{CO}_{2} /{ }^{12} \mathrm{CO}_{2}$ labelling. Plant Cell Environ. 22, 851-858.

Geleta, B., Atak, M., Bänziger, P.S., Nelson, L.A., Baltensperger, D.D., Eskridge, K.M., Shipman, M.J., Shelton, D.R., 2002. Seeding rate and genotype effect on agronomic performance and end-use quality of winter wheat. Crop Sci. 42, 827-832.

Ghaffari, A., Cook, H.F., Lee, H.C., 2001. Simulating winter wheat yields under temperate conditions: exploring different management scenarios. Eur. J. Agron. 15, 231-240.

Gooding, M.J., Ellis, R.H., Shewry, P.R., Schofield, J.D., 2003. Effects of restricted water availability and increased temperature on the grain filling, drying and quality of winter wheat. J. Cereal Sci. 37, 295-309.

Grafius, J.E., 1972. Competition for environmental resources by component characters. Crop Sci. 12, 364-378.

Guarda, G., Padovan, S., Delogu, G., 2004. Grain yield, nitrogen-use efficiency and baking quality of old and modern Italian bread-wheat cultivars grown at different nitrogen levels. Eur. J. Agron. 21, 181-192.

Hiltbrunner, J., Liedgens, M., Stamp, P., Streit, B., 2005. Effects of row spacing and liquid manure on directly drilled winter wheat in organic farming. Eur. J. Agron. 22, 441-447.

Holen, D.L., Bruckner, P.L., Martin, J.M., Carlson, G.R., Wichman, D.M., Berg, J.E., 2001. Response of winter wheat to simulated stand reduction. Agron. J. 93, 364-370.

Justes, E., Mary, B., Meynard, J.M., Machet, J.M., Thelier-Huches, L., 1994. Determination of a critical nitrogen dilution curve for winter wheat crops. Ann. Bot. 75, 397-407.

Mariotti, M., Arduini, I., Lulli, L., 2003. Traslocazione della biomassa nel frumento duro durante il grain-filling. In: Mori, M., Fagnano, M. 
(Eds.), Proceedings of the XXXV Congress of the Italian Society of Agronomy. Napoli, 16-18 September. Imago Media, Caserta, Italy, pp. $339-340$.

Marshall, G.C., Ohm, H.W., 1987. Yield responses of 16 winter wheat cultivars to row spacing and seeding rate. Agron. J. 79, 1027-1030.

Moonen, C., Masoni, A., Ercoli, L., Mariotti, M., Bonari, E., 2001. Longterm changes in rainfall and temperature in Pisa, Italy. Agric. Med. 131, 66-76.

Ozturk, A., Caglar, O., Bulut, S., 2006. Growth and yield response of facultative wheat to winter sowing, freezing sowing and spring sowing at different seeding rates. J. Agron. Crop Sci. 192, 10-16.

Papakosta, D.K., Gagianas, A.A., 1991. Nitrogen and dry matter accumulation, remobilization and losses for Mediterranean wheat during grain filling. Agron. J. 83, 864-870.

Pheloung, P.C., Siddique, K.H.M., 1991. Contribution of stem dry matter to grain yield in wheat cultivars. Aust. J. Plant Physiol. 18, 53-64.

Prystupa, P., Savin, R., Slafer, G.A., 2004. Grain number and its relationship with dry matter, $\mathrm{N}$ and $\mathrm{P}$ in the spikes at heading in response to $\mathrm{N} \times \mathrm{P}$ fertilization in barley. Field Crops Res. 90, 245-254.

Przulj, N., Momcilovic, V., 2001a. Genetic variation for dry matter and nitrogen accumulation and translocation in two-rowed spring barley. I. Dry matter translocation. Eur. J. Agron. 15, 241-254.

Przulj, N., Momcilovic, V., 2001b. Genetic variation for dry matter and nitrogen accumulation and translocation in two-rowed spring barley. II. Nitrogen translocation. Eur. J. Agron. 15, 255-265.

Read, D.W.L., Warder, F.G., 1982. Wheat and barley responses to rates of seeding and fertilizer in Southwestern Saskatchewan. Agron. J. 74, 33-36.

Siddique, K.H.M., Kirby, E.J.M., Perry, M.W., 1989. Ear-to-stem ratio in old and modern wheats; relationship with improvement in number of grains per ear and yield. Field Crops Res. 21, 59-64.
Spink, H.J., Semere, T., Sparkes, D.L., Whaley, J.M., Foulkes, M.J., Clare, R.W., Scott, R.K., 2000. Effect of sowing date on the optimum plant density of winter wheat. Ann. Appl. Biol. 137, 179-188.

Steel, R.G.D., Torrie, J.H., Dickey, D.A., 1997. Principles and Procedure of Statistics: A Biometrical Approach. McGraw-Hill, New York.

Tahir, I.S.A., Nakata, N., 2005. Remobilization of nitrogen and carbohydrate from stems of bread wheat in response to heat stress during grain filling. J. Agron. Crop Sci. 191, 106-115.

Tompkins, D.K., Fowler, D.B., Wright, A.T., 1991a. Water use by no-till winter wheat. Influence of seed rate and row spacing. Agron. J. 83, 766-769.

Tompkins, D.K., Hultgreen, G.E., Wright, A.T., Fowler, D.B., 1991b. Seed rate and row spacing of no-till winter wheat. Agron. J. 83, 684-689.

Van Herwaarden, A.F., Farquhar, G.D., Angus, J.F., Richards, R.A., Howe, G.N., 1998. 'Haying-off', the negative grain yield response of dryland wheat to nitrogen fertiliser. I. Biomass, grain yield, and water use. Aust. J. Agric. Res. 49, 1067-1081.

Wall, G.W., Kanemasu, E.T., 1990. Carbon dioxide exchange rates in wheat canopies. Part I. Influence of canopy geometry on trends in leaf area index, light interception and instantaneous exchange rates. Agric. For. Meteorol. 49, 81-102.

Whaley, J.M., Sparkes, D.L., Foulkes, M.J., Spink, J.H., Semere, T., Scott, R.K., 2000. The physiological response of winter wheat to reductions in plant density. Ann. Appl. Biol. 137, 165-178.

Wilson, J.A., Swanson, A.F., 1962. Effect of plant spacing on the development of winter wheat. Agron. J. 54, 327-328.

Wood, G.A., Welsh, J.P., Godwin, R.J., Taylor, J.C., Earl, R., Knight, S.M., 2003. Real-time measures of canopy size as a basis for spatially varying nitrogen applications to winter wheat sown at different seed rates. Biosyst. Eng. 84, 513-531.

Zadoks, J.C., Chang, T.T., Konzak, C.F., 1974. A decimal code for the growth stages of cereals. Weed Res. 14, 415-421. 